\title{
3 Albanian migration in Greece and Austria: exploring the links between integration and transnationalism
}

\subsection{Migration patterns of Albanians in Greece and Austria}

Since the 1990s, Albania has witnessed one of the greatest and most dramatic migration flows in its history. Pictures of desperate Albanians 'breaking the walls' of Western embassies or of desperate Albanian refugees piled into crowded, rusty ships to escape a country spiralling into political and economic chaos became part of the iconography of global migration in the 1990s (KING and MAI 2008).

Over a million Albanians (about $27.5 \%$ of the total Albanian population and $35 \%$ of the active population) migrated abroad. In 2017, Albania had about 1.5 million citizens outside its territory, amounting to about one third of the country's population (INSTAT 2017a). ${ }^{24}$ The majority of Albanian migrants are settled in the neighbouring countries of Italy $(455,468)$ and Greece $(429,428)$ (UNDESA 2017), however with a growing trend of presence in other European Union countries as well as in North America (USA and Canada). The sudden massive migration outflows that occurred as the country moved almost overnight from absolute isolation to large-scale migration, the ratio of the number of emigrants to the country's population, and the typology of these moves make Albania a significant and unique case on the migration map of the world (KING and VulLNETARI 2009; VulLNETARI and King 2011).

The 'uniqueness' of Albanian migration is further characterised by the fact that it has been directed almost exclusively towards two neighbouring countries: Greece and Italy (LABRIANIDIS and KAZAZI 2006). In stressing that for most Albanians, migration was the only possible way to survive an economic crisis (as a consequence of the wider postcommunist political transformation of the country), BARJABA and Perrone (1996, p. 133) use the phrase 'migration of economic refugees', whilst VAn Hear (1998) refers to a new migration order. KING (2005) goes a step further by pointing out that emigration from Albania represents a unique laboratory for the study of migration and development. The exceptionality of Albanian migration consists in: (a) Guaranteeing the economic survival of Albanian society. (b) Its overall magnitude in relation to the size of the Albanian population. (c) Its sudden and forceful emergence after fifty years of internal mobility restrictions and international isolation. (d) Its interconnection with internal migration, and the emergence of trafficking and organised crime (MAI 2003, p. 940). However, the fundamental need to improve economic well-being through migration cannot be separated from the aspiration of Albanians to seek a socio-political alternative to a fifty year authoritarian regime. From this perspective, Albanian migration can be seen as an

24 According to INSTAT, the average population numbered 2,873,457 in 2017. The difference between the data registered in the National Civil Status Register and the average population for 2017 can be estimated as an indirect indicator of the number of Albanian citizens living abroad. 
intrinsically political act that challenged the model of personhood that was consistent with the principles of communist dictatorship (MAI 2001).

Today, emigration of Albanian citizens, in particular toward European Union (EU) countries, continues despite the constant improvement of living conditions in the country, a net stable growth of the Albanian economy, and constant improvement of public safety (RoA 2017). This is also confirmed by the fact that the number of Albanian citizens who applied for asylum in EU Member States (11,040 in 2013; 12,295 in 2014) have been largely growing during 2014-2017. According to INSTAT (2017b), five factors are estimated to currently influence emigration toward the EU. These include the opportunity to work abroad (84\%), family reunification $(4.6 \%)$, followed by the unemployment in Albania (4.2\%), opportunity to study abroad (3.5\%), and other factors (3.6\%). Additional pull factors are higher quality of training and educational opportunities abroad. In turn, weaknesses of public institutions and public services have served as push factors negatively affecting migrants' efforts and perspectives to return and settle in Albania.

On the other hand, the significant impact of the large-scale migration on the country's social and economic development should be taken into consideration. Remittances have long helped to overcome poverty in the aftermath of the communist regime and for many years continued to make an important contribution to the Albanian economy. Although Albania continues to be heavily dependent on remittances, the inflows gradually declined during the economic crisis in Southern Europe from the peak of EUR 952 million in 2007 to EUR 547 million in 2013. Since then the levels have recovered to reach EUR 637 million in 2017 and are expected to rise further with the return of growth in host countries (Greece and Italy), providing migrant households and local economies with an extraordinary and irreplaceable source of finance (GOVERNMENT of Albania and IOM 2018).

\subsubsection{Albanian migration in Greece}

Since the 1990s, Albanians have constituted the largest migrant community in Greece. Official data refers to 362,825 Albanians (out of 520,260 TCNs, or $67 \%$ of the total migrant population) staying legally in Greece (GreEk Ministry of Migration Policy 2018). During the 1990s, immigration from Albania was predominantly irregular with most of the immigrants being men, later followed by their spouses and children. The Presidential Decree 359/1997 introduced the first regularization programme for irregular immigrants in Greece. During the first phase of implementation, two-thirds $(241,561)$ of immigrants who were regularized were from Albania. The efforts to regularize the immigrant population along with the branding of deportations as 'irregular' resulted in the decrease of irregular immigration from Albania. Furthermore, the stricter border controls associated with immigrants and the insistence of the Greek state that immigrants contribute to social insurance contributed to the permanent stay of Albanian immigrants in Greece (BALDWIN-EDWARDS 2004, p. 62). 
Since 2000, faced with the large scale of (irregular) migration, the Greek state realized, albeit rather belatedly, that migration had become a permanent feature and that migrants were there to stay for good. Thus, it passed two consecutive laws, 2910/2001 and 3386/2005, which adopted new regularization programmes and most importantly for the first time introduced the issue of social integration of immigrants. Toward the end of the 2000s, the socio-economic integration of Albanians finally started to be institutionalized and to become established. After years of being subject to a very particular regime of semi-regularity, the number of long-term residents and naturalized Greek citizens had shown relative growth by the beginning of the 2010s (MinISTRY OF Migration Policy 2018).

The 2010s gave rise to a new configuration of Albanian migration in Greece, differing from that of the1990s and 2000s. It consisted of national and supranational institutional developments such as visa liberalization, a new migration and integration law passed in 2014, and the introduction of an EU long-term residence permit. Systemic features such as a restructuring of the labour markets of Greece hit by the economic crisis added to the endogenous dynamics of migratory flows. More concretely, Albanians had long struggled to overcome irregularity and largely managed to do so, had it not been for the 2008 economic crisis that hit Greece and thus left many among them unemployed. The de-regularisation of male wage earners, particularly those working in the construction sector, often led to entire families losing their legal status. In addition, protracted unemployment of men and a reduction of work/income for women made living in Greece economically unsustainable to many. The transition in which Albanians found themselves to a degree reversed the process of integration. At the same time, the application of the long-term validity of residence permits adopted by the Greek government in 2014, albeit with significant delay, granted Albanian migrants the opportunity to return to Albania or to move elsewhere (within the Schengen area) with the option of regularly returning to Greece when work is available. In contrast, Albanian migrants with temporary residence permits (which numerically were the majority) were faced with serious difficulties in renewing their residence permits due to unemployment and financial hardships in Greece. As few immigrants had secured permanent residence and equal rights under Greece's rigid and restrictive residence policies, many of them have lost their jobs, their legal status and therefore their basic social entitlements.

Since their socio-economic relations and stay must be re-evaluated, they came under pressure to re-establish or strengthen ties to their networks in Albania or elsewhere, because of the need to face the consequences of the crisis, while return flows increasingly prevailed (GEMI 2015, p. 36). A study carried out by the IOM and INSTAT (2014) recorded 133,544 returns in the 2009-2013 period alone. The majority of returns were voluntary and concerned Albanian migrants who had previously been in Greece (70.8\%) and Italy (23.7\%), whilst the main reasons for return was the loss of a job in the country of destination (NESTURI 2014, p. 10). Based on anecdotal evidence, KING (2017) highlights that the severe economic crisis in Greece has caused a significant return flow, which in turn has led to a significant reduction in the 'stock' of Albanians in Greece 
(ibid., p. 18). However, the returnees' trajectory is not seen as the end of the migration project per se or as a failure either. It has often involved skilled migrants and entire families who have lost their place on the Greek labour market. At the same time, circular and transnational movements for seasonal workers and often also informal employment in specific sectors of the economy (e.g., agriculture and tourism) have emerged as the most frequent means by which the migration of Albanians to Greece takes place (GEMI 2013). In addition, studies (i.e. GEMI 2015) have shown that a significant number of Albanians seems to reconsider their stay in both countries and many are heading back to Albania or moving towards other industrial countries of Western Europe with the aim of finding employment opportunities there. Today, after almost three decades of immigration experience, in the context of the economic crisis and at the different crossroads at which these three countries stand before the EU, the options of return, transnational and circular migration, and re-migration become all the more important on the agenda of the Albanian migrant household. In this context, the interplay of and interconnectedness between being settled and being mobile unfold, regardless of the lack of targeted integration and/or re-integration policies at a governmental and/or intergovernmental level in Greece and Albania.

Lastly, as far as integration patterns are concerned, the integration trajectory of Albanians in Greece is that of partial integration, which comes as a result of the differential exclusion and the non-interventionist integration policies implemented until the end of the 2000s (Gemi 2017, p. 257). Albanians, in response, seem to have adopted a strategy characterized as 'mimesis' (PALADINI 2014, p. 112) or in more politically correct terms assimilation (through mimesis). In a way, Albanians have persistently sought to blur into the Greek social fabric, making themselves as invisible as possible by changing their names (as it happened in Greece) and religious identity (if any had existed). The term asymmetric assimilation adopted by KING and MAI (2008, p. 117) emphasizes the paradox of a community which is at the same time the most stigmatized and the most integrated and similar to the population of the host country (PALADINI 2014, p. 112).

\subsubsection{Albanian migration in Austria}

The Western Balkans is an extremely important source region for Austrian immigration. Indeed, the largest migration population in Austria is from the Western Balkans, with Serbia $(181,700)$, Bosnia and Herzegovina $(94,000)$ and the Former Yug. Rep. of Macedonia $(21,700)$ ranking among the 15 top nationalities in the country in 2015 (OECD 2017). Due to its historical position (having been the former centre of the multi-ethnic Austro-Hungarian Monarchy), Austria has traditionally hosted large influxes of populations mostly from the Balkans. The recent high numbers are mainly an outcome of economically motivated former guest-worker immigration, which started during the early 1960s and intensified during the early 1970s. An additional factor was the high numbers of Bosnian refugees moving to Austria during and after the Bosnian 
War of 1992-95. In the period of 2004-2013 alone, Austria had shown a migration surplus of 337,000 people, 138,000 of whom were from the Western Balkan countries, thus representing $41 \%$ of the net migration (FASSMANN 2017, p. 127). During the same period, a total number of 2,961 migrants from Albania have registered as legal residents in Austria (Statistik Austria 2018). Since 2002, the number of Albanian legal residents in Austria has risen by 52.5\% (from 1,833 in 2002 to 3,861 in 2017) (ibid.). Again, according to Statistik Austria (2018), in 2017, 3,861 registered foreigners had been born in Albania, while 2,378 were Albanian citizens.

From a community perspective, the total number of Albanians (both from Kosovo and from Albania) in Austria is estimated at approximately 80,000 people, of whom more than 35,000 are settled in Vienna (Interviews no. 1, 3 and 9, Vienna). According to estimated data provided to the Albanian Embassy in Austria by Albanian migrants' associations in the country, the distribution of the Albanian population in Austria (citizens of the Republic of Albania) is configured as follows:

Table 1: Estimated numbers of Albanians in Austrian Federal Provinces ${ }^{25}$

\begin{tabular}{|c|l|r|}
\hline A/A & Federal provinces & $\begin{array}{c}\text { Estimated numbers of } \\
\text { Albanians living in Austria }\end{array}$ \\
\hline 1 & Vienna and suburbs & $20,000-35,000$ \\
\hline 2 & Styria & 20,000 \\
\hline 3 & Upper Austria & 15,000 \\
\hline 4 & Salzburg & 7,000 \\
\hline 5 & Tyrol & $2,000-3,000$ \\
\hline 6 & Carinthia & 1,500 \\
\hline 7 & Lower Austria & 500 \\
\hline 8 & Burgenland & 500 \\
\hline & Total & 81,600 \\
\hline
\end{tabular}

Source: Author's compilation based on data provided by Interviews no. 1 and 3, Vienna; numbers for Vorarlberg were not available

However, in the opinion of the Albanian Ministry of Foreign Affairs, there are about 2,800-4,000 Albanians (only from Albania) that are actually accommodated in Vienna (Interview no. 1, Vienna). An estimated 18,500 people of Albanian origin are registered in voters' lists for the electoral constituency of Vienna's local government (Interview no. 3, Vienna). In comparison to Greece, the number of Albanian migrants in Austria is very small. Nevertheless, what makes the comparison interesting is the typology of migration patterns and the human geography of Albanian migration to Austria.

25 There are no clear statistics on the exact number of Albanians originating from the state of Albania. These numbers rather reflect the number of ethnic Albanians (mainly from Kosovo and North Macedonia) living in Austria. 
In terms of migration patterns, Albanian migration in Austria and more specifically in Vienna is linked to the historical and political, economic and cultural ties between the two countries at the end of the $19^{\text {th }}$ century and the beginning of the $20^{\text {th }}$ century. It is no coincidence that during the emigration exodus in 1990-1991, the first Albanians who settled in Vienna were politically persecuted descendants of former powerful Albanian families of bey ${ }^{26}$, for instance those of Eqerem Bej Vlora and Ali Kelcyra (Interview no. 4, Vienna). Their strong ties with the Austrian establishment, particularly during the realms of the Erste Republik Österreich and Ständestaat, were deeply rooted in the geography, (i.e. Austria as a hub between west and east, and Albania located at the heart of the Balkans), as well as in economic and geopolitical interests, including the banking sector. At the same time, the universities of Vienna and Graz, respectively, have been traditionally qualified as the best tertiary educational institutions in Europe that have hosted Albanian academics and students as early as the 1920s. Even at the beginning of the 1990s, the first flows of Albanians predominantly had an intellectual background.

Today, Albanian students are numerically a very significant group, not only in relation to the Albanian community, but also compared to the overall student community in Austria. More than 2,000 Albanian students study at various Austrian universities (Interview no. 3, Vienna). Meanwhile, Albania is ranked among the top eight countries with a large number of university students in Austria (BIfFL 2018, p. 75). The international mobility of students, graduates, as well as scientific and artistic university staff is deemed to play a very important role in the internationalization of Austrian higher education institutions. Furthermore, the government has sought to ease the conditions for international students from third countries to remain in the country upon graduation from an Austrian higher education institution and search for a job (MUSIL and REYHANI 2012, p. 11). On the other hand, in the framework of the Central European Exchange Programme for University Studies (CEEPUS) ${ }^{27}$, there is an agreement between the governments of the Republic of Austria and the Republic of Albania on scientific and technological co-operation (MusiL and REYHANI 2012, p. 67).

Following the economic recession in Greece, it is estimated that approximately 1,000 to 1,500 Albanians migrants have moved to Austria from Greece lately. They are predominantly men, holders of Greek passports or long-term residence permits. Most of them are semi-skilled workers that have initially moved to Vienna alone in search of employment and better life perspectives, later followed by their spouses and children (Interview no. 9, Vienna). This might be due to the fact that the employment situation in Austria remained stable at about 75\% during and after the economic crisis (MIPEX 2015b). At the same time, integration policy has made significant progress since 2007, rising 8 points on the MIPEX scale, with Austria ranked 20th out of the 38 MIPEX countries by the end of 2014. In an attempt to summarise the above, it could be

26 Bey was the traditional ruler or the governor of a province in the Ottoman Empire.

27 CEEPUS is a multilateral exchange programme within Central and Eastern Europe that was initiated by Austria in 1995 and encompasses universities from 16 Central and Eastern European countries, including Albania. 
concluded that, unlike Greece, the patterns of Albanian migration in Austria and particularly in Vienna could be characterized as 'elitist' and/or 'eclectic' rather than large-scale and/or irregular.

\subsection{Integration}

Integration is not a linear or uniform process. It is an evolutionary, dialectical process, which develops in various spheres with different rhythms. It involves different actors, including the country of destination, the country of origin and migrants themselves. It assumes different forms and follows different strategies at different stages. The basic assumption behind the analysis of integration consists in its conceptualization as a process of social change that involves both migrants and the host society (KOHLBACHER 2017, p. 168). In line with this view, the basic idea is the convergence of social outcomes, where policy inputs on the basis of equal opportunities may produce equal outputs and consequently ensure the well-being of the entire population. It first denotes, however, that it is primarily the host country's responsibility to ensure that migrants enjoy the same rights, allowing them to participate on equal terms in the economic, social, political and cultural life of the receiving country. Secondly, it implies that migrants respect the host society's fundamental rules and values, and participate actively in the integration process (without relinquishing their ethnic identity), while developing feelings of belonging and identification (Kohlbacher 2017, p. 170; HecKmann 2006, p. 25; Gemi 2017, p. 13). In this context, integration is perceived as a process that covers three analytically distinct dimensions of becoming, or not becoming, an equal part of society. These are summarized as (a) the legal-political, (b) the socio-economic, and (c) the cultural-religious. The first refers to the basic question of whether immigrants are regarded as 'legal' members of the political community with corresponding rights and statuses. The second dimension pertains to rights related to institutionalized access to the socio-economic sphere such as the labour market, housing and education. The third refers to perceptions and practices that involve the rights of cultural, ethnic or religious groups to manifest themselves, as well as the mutual acceptance of difference and diversity (GARCÉs-MASCAREÑAS and Penninx 2016, p. 14; Penninx 2004, p. 6).

\subsubsection{Legal-Political Dimension}

With regard to the legal dimension, the residence permit defines the legal status of migrants and is one of the key institutional and structural factors that affect the outcome of the integration process. The more stable and long-standing the status of residence, the better and safer the prospects for the social integration of immigrants. For migrants, legal status is understood to entail the principles of equality, freedom and access to the same rights as those enjoyed by the host population. Some of the indicators measuring 
the legal-political dimension could be residence permits and related rights, citizenship, political participation, and civil society participation.

In Austria, the majority of Albanians are either holders of a long-term residence permit (EU permit) or an Austrian passport by naturalization. The first category enjoys fully fledged social and economic rights, but not political rights. According to a key informant, about 15,000 Albanians are registered in the electoral list, which indicates that they have become Austrian citizens with the right to vote (Interview no. 3, Vienna). Another significant legal category is that of Albanian students who have graduated from Austrian universities. As one of the interviewees suggests:

"The number of Albanian students that originally came into the country for study reasons and then settled for good is believed to be about 2,500-3,000." (Interview no. 9, Vienna).

As was mentioned earlier, Albania is ranked among the top eight countries with a large number of university students in Austria (BIFFL 2017, p.75). According to an interviewee, this is due to low university fees, the easy access and the high quality of tertiary education in Austria:

"The reason for choosing Austria had to do first with my own desire and need to leave Greece (Albanian of second generation) and secondly my cousin introduced me to the tertiary education system of Austria that is cheap, accessible and of high quality." (Interview no. 12, Vienna).

In fact, the international mobility of students, graduates, as well as scientific and artistic staff is regarded as a very important part of the internationalization of the Austrian tertiary education system.

"I got the high school diplomas from the Austrian Information Technology School 'Peter Mahringer' based in Shkoder. After graduating in 2016, I enrolled at the Vienna Economic University. I do not pay any fees since my high school diploma was issued by an Austrian institution." (Interview no. 13, Vienna).

This is further supported by another key informant who put emphasis on the highly skilled profile of Albanian migration in Austria:

"There are more than 2,000 Albanian students that are currently enrolled in Austrian universities and many other Albanian professors who teach at Austrian universities. There are also distinguished Albanian artists..." (Interview no. 3, Vienna).

In addition, the Austrian government has sought to facilitate the legal terms and conditions for TCN students ${ }^{28}$ to work during studying and to remain in the country to work after graduation from an Austrian university (MusiL and ReyHani 2012, p. 11). A student interviewee confirms the above:

$28 \quad$ Legislation on entry and stay for TCN students in Austria is regulated according to the EU Students Directive. 
"I have mostly worked as waitress. Sometimes regularly, sometimes irregularly and this because of my student status. Now, the law has changed. Students are allowed to work 20 hours instead of the 10 hours provided by the previous law." (Interview no. 12, Vienna).

Furthermore, the multilateral Central European Exchange Programme facilitates studying in Austria for University Studies (CEEPUS) initiated by Austria in 1995, with Albania being one of the main partners (Musil and ReYHANi 2012, p. 67). Notwithstanding the aforementioned, the field work revealed getting a student visa as the main barrier to ensure legal status. As one of interviewees pointed out:

“...Every year I face problems with the visa's renewal without any concrete and justified reason. There have been cases when I had to wait from two to three months to get the visa while the previous one had already expired." (Interview no. 5, Vienna).

One student interviewee supports that the change in civil servants' behaviour has come as a result of the recent refugee crisis and the rise of a xenophobic attitude:

"In the beginning, things were going according to plan. Since 2015, however, the attitude of civil servants responsible for the renewal of stay permits has completely changed. One could wait for several months for a visa to be issued and what's more problematic is the fact that they ask for additional documents without providing any reasonable argument." (Interview no. 12, Vienna).

Another migrant category is that of seasonal Albanian workers coming to Vienna to work irregularly on a seasonal basis:

"There is a small number of Albanian citizens who enter Austria and stay only for 3 months - as much as biometric passports allows - to work in construction sites or to do babysitting. They are usually supported and facilitated by Albanian and Kosovar networks here in Vienna." (Interview no. 9, Vienna).

The people involved tend to make use of transnational community networks. Facilitated by geographic proximity, these networks tend to favour cross-border movement of irregular migrants in response to economic opportunities. Last, the fieldwork showed another category of Albanian investors (with former politicians included among them), which benefits from the stability and prosperity of the Austrian economy and its banking system. This is reinforced by the fact that the Austrian Government has created a network of bilateral investment treaties (BITs) with 62 countries, including Albania, for the promotion and protection of investment (BIFFL 2017, p.140).

In the meantime, in Greece, the greatest obstacle to the integration of migrants is the legal framework. As a key informant maintains:

"This is due to the fact that legalization programmes have failed to create a stable and permanent mechanism for the legalization of migrants and their integration into Greek society." (Interview no. 11, Athens). 
Concerning regular migration, Greece's economic crisis has led to an increase in unemployment and the displacement of a large number of Albanians, especially those working in the construction sector (Interview no. 3, Athens). The above is broadly confirmed by data provided by the Ministry of the Interior, which suggested that between 130,000 and 140,000 Albanian migrant workers lost their residence permits because they were unable to secure the required number of social insurance stamps to renew their documents (GEmi 2013, p. 4). The Migration and Integration Code (L4251/2014, Article 7) has however facilitated the gradual unification of all long-term residence permits under the EU long-term resident status (L. 4251/14, Article 138). Thus, 10-year permits are no longer renewed automatically as they have been in the past, but are converted to the EU long-term resident status when the conditions are met. In August 2018, the ratio of long-term permits to total residence permits has increased significantly, with long-term permits accounting for $40.45 \%$ of all valid permits compared to $26 \%$ in $2013,33 \%$ in $2014,36 \%$ in $2015,37 \%$ in 2016 and $35.8 \%$ in 2017 (GEMI and TRIANDAFYLLIDOU 2018). Notwithstanding the improvements made, many Albanians still face serious problems with the renewal of residence permits. A key informant maintains that:

"The difficult task of ensuring the legal status remains a major obstacle to integration along with lack of information, gaps in legislation, and inefficiency of administrative mechanisms." (Interview no. 10, Athens).

It is widely recognized that the model of citizenship is a key variable in assessing integration and migration policies. In fact, it is directly linked to the tradition and history of each nation state in the course of the process of the establishment of state identity. Thus, any form of integration is determined by the way citizenship is perceived. Whether defined formally or in real terms, citizenship in liberal democratic societies means ensuring the individual's rights to fully fledged participation in society. This refers both to the laws and to the institutions of a political system, which determine social interaction and the actors that take part in it (Gemi 2017, p. 39).

Austria has an ethnicity-based model of citizenship, which is known as ius sanguinis. It means that individuals of Austrian origin (i.e. having Austrian parents) are primarily granted citizenship. Such a model has been found to produce restrictive naturalization policies (ВАUвÖск 2006). As one of the interviewees put it:

"In Austria, only Austrian citizens have the right to vote and stand as candidate in elections. Austria has one of the most restrictive laws concerning citizenship in Europe. Thus the political participation and representation of migrants only extend to those who have been naturalized." (Interview no. 3, Vienna).

According to MIPEX (2015b), despite the fact that integration policy has made significant progress since 2007 (rising 8 points on the MIPEX scale), the most problematic policy areas in Austria remain access to nationality and political participation. Austria is among the countries with high barriers to the acquisition of citizenship (BAUBÖCK 2006). This is also confirmed by the available data on naturalization. In 2016 alone, 8,500 
foreigners were granted Austrian citizenship, which amounts $0.7 \%$ naturalisations as a percentage of the foreign population. Interestingly, the naturalisation rate has remained stable for seven consecutive years (2009-2016) (BIFFL 2017, p. 93). An interviewee, who addresses it as follows, also confirms this:

“...only 7 in 1,000 migrants obtain citizenship per year.” (Interview no. 6, Vienna).

Meanwhile, in Vienna, 27\% of residents of voting age have no right to vote, while $21 \%$ of TCNs are excluded from naturalization because of income limits (STADTWIEN 2017, p. 8). A foreign citizen should legally stay in Austria for ten consecutive years in order to be eligible for citizenship. Furthermore, such a person should have sufficient means of subsistence (meet the income threshold without receiving social assistance), hold a B1 (or B2) certificate of proficiency in the German language, produce the renunciation of his or her former nationality, and pass a written test about the democratic system and history of Austria and Vienna. This is also mentioned by one of the interviewees, who described the test as follows:

"The written multiple choices test is articulated around three chapters: the history of Austria, the history of Vienna and the democratic values." (Interview no. 4, Vienna).

In principle, the Austrian Nationality Act does not allow dual citizenship. However, there are exceptions, including persons who had obtained dual citizenship by birth or those who are deemed important for Austrian interests due to exceptional achievements. The following excerpt illustrates a similar case:

"My daughter holds dual citizenship: Austrian (from me) and Macedonian (from her mother)... since her mother is not an Austrian citizen." (Interview no. 4, Vienna).

Similarly, in Greece, the citizenship has been based predominantly on the ius sanguinis principle. Importantly also, citizenship is defined in ethnic-genealogical and cultural terms with little reference to civic elements and the possibility to 'become' rather than 'be born' Greek (TRIANDAFYLLIDOU et al. 2015). As an interviewee put it:

"For the TCNs, until March 2010, the process of applying for citizenship was very long, costly, and with a very uncertain outcome or no outcome at all, even for migrants who had lived in Greece for more than 20 years and meet all the requirements." (Interview no. 3, Athens).

It is important to highlight that the ius sanguinis logic was applied diferently for different groups of co-ethnics (omogeneis in Greek). In contrast to Pontiac Greeks (coming from the former Soviet Republics), who benefitted from citizenship attainment, co-ethnics from Albania, the so-called Voreioipirotes, were faced with a tacit ban on citizenship acquisition until 2007 (BALTSIOTIS 2014, p. 7). The policy changed in November 2006 when the then Greek government (New Democracy) decided to promote 
the procedures for granting the Greek citizenship to co-ethnics from Southern Albania. Naturalisations of Greek Albanian co-ethnics rose exponentially to over 10,000 people per year and to approximately 50,000 people in the period 2007-2010 (TRIANDAFYLLIDOU et al. 2015). Concerning the second generation, the situation appeared to be even more problematic:

"(There is) a second generation of the young, who was born, raised and has attended all the levels of the Greek educational system, from kindergarten to the University of Athens, and when it comes to working rights, he/she has no access to employment at public institutions." (Interview no. 5, Athens).

In an effort to normalize the situation, in 2015, the newly-elected government (of SYRIZA) reformed the citizeship law, making naturalization possible with a simple declaration/application for children born in Greece and for youths who have completed the greater part of their education in Greece. ${ }^{29}$ However, an interviewer maintains that the above law, while improving the positition of the second generation, failed to address the problem of the first generation:

"... in fact, notwithstanding the positive effects on the second generation, the new citizenship law (2015) failed to facilitate the naturalization of the first generation migrants, who came to Greece in the 1990s and have been living in Greece since then." (Interview no. 14, Athens).

For 2017, a significant increase in the number of citizenship acquisitions mainly through birth or study can be observed, including an increase in acquisitions of citizenship by non-co-ethnics (L. 4332/2015). Moreover, an increase is also noted in the number of naturalisations, with 56,274 Albanian nationals - or $85 \%$ of the total number of naturalized immigrants - having obtained Greek citizenship in the 2010-2014 period. In addition, the naturalisation provisions that came into effect in 2015 have led to increasing numbers of citizenship acquisitions mostly by children born in Greece, or children who came to the country at a young age and have attended Greek schools. These account for 33,000 naturalisations in 2017, of which about two-thirds were for children of the second or 1.5 generation. With regard to their previous nationality, the vast majority, namely 28,536 persons, were Albanians (GEMI and TRIANDAFYLLIDOU 2018, p. 6).

Theoretically, political integration and participation could be described as a continuum with socio-political exclusion at the one end, and the full exercise of political rights (citizenship) at the other. This in turn has resulted in the development of different forms of political action, which include, among others, the parliamentary, electoral and consultative bodies, pressure groups and ethnic/immigrant organizations. Among the main determinants that affect the organizational behaviour and the presence of immigrants in the public life of the country of settlement are: (a) Migration policy (such

29 Primary education: 9 years required; secondary: six years required and university, for which a secondary education certificate is also required. 
as access to citizenship, voting rights and integration policies). (b) The influence of the country of origin. (c) Collective identities (such as the sense of belonging to a particular ethnic, religious and/or racial group) (Koopmans et al. 2005). With regard to political participation at the local level, 27\% of Viennese residents above 16 (who are formally eligible) are currently excluded from voting due to the legal restrictions on the voting rights of TCNs (STADTWIEN 2017). With regard to formal political participation, the low level, if any, of Albanians in Viennese political life is illustrated in a very characteristic way in the following excerpt:

"Among 100 MPs in the Vienna Parliament, only two are of migrant background (Turks) ... 15,000 Albanians took part in previous elections, but no one voted for candidates coming from their community. In proportion to the size of the community, Albanians in Vienna may have elected at least two representatives in the Parliament of Vienna. " (Interview no. 3, Vienna).

According to the same interviewee, it is the case when the manipulative role of the country of origin, combined with weak bonds of collective ethnic identity, work as a deterrent force to active participation and representation of Albanians in public life:

"In contrast to Kosovars, Albanians are not organized, reflecting, in a way, the fragmentation of Albanian society back in Albania." (Interview no. 9, Vienna).

In Vienna, there is a wide spectrum of migrant associations and organisations, whose main activities are cultural, political, religious, or sport-related in nature. The same also holds true for Albanian migrants:

"The Albanian community in Vienna is relatively well-organized. There are twenty Albanian associations in total, but not all of them are active. Most of them are focused on cultural and sport activities." (Interview no. 3, Vienna).

The main form of Albanian migrants' organisations is that based on a common ethnic background. The following excerpt clearly illustrates this:

"There are more than 100 Albanian associations from Albania, Kosovo and Macedonia in Austria, but only 1/3 of them are active. For us (the Albanian state), the diaspora are all ethnic Albanians." (Interview no. 1, Vienna).

In practice, however, the City of Vienna makes little distinction between migrants' ethnic, national and religious organisations. To this end, it provides funds to migrant organizations and other NGOs in order to offer services related to legal issues, community networking and free language courses (Interview no. 3, Vienna).

In Greece, the prevailing conditions of insecurity and the lack of long-term prospects are major obstacles for participation in public life (Interview no. 14, Athens). In fact, the participation of Albanian migrants in civil society institutions (non-governmental organizations, cultural associations) is at a low level and mainly revolves around issues related to the renewal of residence permits, rather than around issues related to the social and political requirements for participation and presentation in Greek society (Interview no. 15, Athens). An interviewee addresses it as follows: 
"The Greek opportunity structure provides incentives neither for formal, nor for informal political participation." (Interview no. 10, Athens).

Since 2010, the highest representation platform in local government has been the Migrant Integration Councils (MICs) (Interview no. 4, Athens). They were established in the course of a major administrative and local government reform, known by the name of 'Kallikratis' in $2010^{30}$. These councils function as consultative bodies to the municipal authorities. However, in practice things are different:

"The MIC has no legal status; it is just an advisory body. The migrant communities participating in MIC and their initiatives are under the aegis of the chair of MIC, who is appointed by the Mayor. For example, a resolution may be discussed in the municipal council only if it is approved by the chair." (Interview no. 4, Athens).

The main obstacle in promoting the role of the MICs has been the lack of political will and political interests in empowering them. However, MICs were introduced around the same time as the local voting rights with Law 3838/2010. The suspension of local migrant rights in the aftermath of the above-mentioned Council of State decision has undermined those original goals and expectations. As TCNs do not have local voting power, they cannot rally the support of, and exercise pressure upon local and national authorities to respond to their problems and demands (Interview no. 5, Athens). The following excerpt describes the situation:

"Unfortunately, during the first period of operation, the first registered members of the MIC of Athens were political parties or NGOs affiliated to political parties. This therefore acts corrosively because they in reality promote their specific agenda." (Interview no. 4, Athens).

\subsubsection{Socio-Economic Dimension}

The socio-economic dimension addresses the social and economic position of the migrant population, irrespective of their citizenship. This approach denotes a process aiming at ensuring the same living and working conditions as well as equal rights among native and immigrant populations. Within this dimension, the position of immigrants can be analysed by looking at their access to and participation in domains of education, the labour market, and housing.

Language and education: the discussion on migration and integration includes an important dimension: the role of proficiency in the language of the host country. The key factor of socio-economic integration in relation to linguistic diversity is not, however, the knowledge of the language or languages per se, but communication. Meanwhile, many countries are currently promoting 're-nationalisation' with respect to language

30 Article 78 of Law 3852/2010 (07.06.2010) on the 'New Architecture of the structure of Local Authorities and Decentralized Administration'. 
and culture (WODAK 2017, p. 122), an approach that is closely tied to the policy of recognition (BAUBÖCK 2011). In this sense, both education and the acquisition of language skills (as a prerequisite for belonging) are becoming increasingly important at every stage of immigrants' life cycle.

In Austria, proficiency in the German language is a necessary condition for migrants' integration and their participation in social and economic life:

"An integration priority in Vienna is language learning. It is mandatory, and the essential part of the integration agreement at national level. Migrants usually get funds for learning, contrary to EU citizens who don't get funded and don't sign any integration agreement." (Interview no. 10, Vienna).

Furthermore, potential migrants have to acquire a Rot-Weiss-Rot Card before entry to Austria, although this does not apply to highly skilled migrants. Some key arguments behind the compulsory nature of post- and pre-arrival integration tests (including language) refer to its 'emancipatory' benefit in terms of gender equality. It is also seen as a necessary instrument to overcome a presumed lack of willingness to integrate (Perchinig 2012, p. 89). It is not coincidental that in 2017, the Integration Act (Integrationsgesetz IntG) focussed on the right to language and orientation courses and the duty to cooperate, along with related sanctions (INTEGRATION Aст 2017, p. 4).

Since 2011, the City of Vienna and the Ministry of Integration have been offering German courses for migrants. Moreover, the Ministry of Integration delivers obligatory 'value courses' (one day for 8 hours), which every refugee whose application for asylum has been accepted has to attend (WODAK 2017, p. 126). A key informant evaluates the quality of German language courses as follows:

"Austria has good programmes for teaching German to foreigners and high school international students.” (Interview no. 9, Vienna).

In Greece, developments on migration have led to the de facto creation of multicultural or multilingual environments. Nevertheless, various studies examining the level of Greek language acquisition showed that migrants have low linguistic proficiency, while the percentage of immigrants who have attended Greek language courses also appeared to be very low (Baldwin-Edwards 2005; Maroukis 2010; Gemi 2017). The following excerpt illustrates the scope of the problem:

"The absolute lack oflanguage competences deprive them from attending vocational training programmes or any other professional course towards making possible their integration into the Greek labour market." (Interview no. 1, Athens).

Obviously, while most migrants do not learn Greek through organized language programmes, there is also little of an organized institutional framework at both national and local level to ensure this. Meanwhile, the informal pattern of Greek language learning is evidently seen as a factor that leads to the inability of the immigrant population to develop adequate language skills (mostly writing and reading), and to the failure of 
upward mobility. Interestingly, however, Albanians have the highest score of Greek language learning compared with other groups of migrants (GEMI 2017).

Talking about the local level, an interviewee describes the situation in the municipality of Athens as follows:

"The available courses of Greek language are very limited and the participation of migrants is even less limited. Integration, in fact, means the establishment of intercultural dialogue in fields such as health, education, and the cultural. There is a lack of specialized staff in our services. Many migrants do not pay visits to municipality clinics, for instance, because either they do not speak Greek, or, in case of Muslim women, there are cultural differences regarding the health services. In sum, migrants do not have incentives and they are not motivated to get in touch with our municipality structures and services." (Interview no. 3, Athens).

Paradoxically, whilst the language proficiency certificate is considered a state responsibility, the resources and means for acquiring it are limited. Regarding access to language courses, the attendance requirements are particularly demanding. Class attendance depends on the attendee's residence permit and employment status. It is not surprising therefore that most migrants learn the (spoken) Greek language through work and television (GEmi 2017, p. 145). At national level, Greece perceives both the national language and culture as gatekeepers to restrict the integration of the 'other'. Hence, the Greek state formulates its migration policy on the basis not only of language proficiency, but also of the national culture and religion (WODAK and BOUKALA 2015, p. 268). More precisely, the law 4115/2013 31 (article 31) maintains, "Sufficient knowledge of the Greek language, history and culture is confirmed by a certificate in Greek language knowledge at B1 Level or Greek language and history testing”.

In terms of access to education, at the kindergarten run by the Municipality of Athens, $18 \%$ of children come from migrant families of various nationalities (Interview no. 8, Athens). However, there are different conditions depending on neighbourhood synthesis, as is illustrated by the following excerpt:

“... at Favierou street $90 \%$ of children enrolled at the kindergarten are of foreign parents. Another characteristic example is the $123^{\text {th }}$ elementary school of Gravia, which is known to be very open to diversity, where currently $90 \%$ of children are of migrant origin. The prevailing nationality is the Albanian, even though their number has significantly reduced compared to previous years." (Interview no. 8, Athens).

For a child to be accepted in a kindergarten, a prerequisite is one of his/her parents to have legal residence in Greece. This changes when it comes to the elementary schools, to which all children, regardless of parents' legal status, have equal access.

31 L. 4115/2013: Organization and operation of the Youth and Lifelong Learning Foundation and the National Agency for Certification of Qualifications and Vocational Orientation. 
Employment is perhaps the most important aspect of integration, since it determines immigrants' living conditions and the fulfilment of their migration goal. Indeed, employment has always been one of the main mechanisms of integration for both the native and migrant population, being at the same time one of the biggest structural challenges in terms of integration and equality. In fact, the position of migrants in the labour market depends upon several structural and non-structural factors, including migration policy, labour market structure, the demographic characteristics of immigrants, residence status, and chosen migration strategies.

In Austria, a labour market governance system facilitates the employment of migrants. This system is based on the social partnership principle, along with a complex system of regional institutions and integration policies at the local level. However, according to statistics, in 2016 , only $56 \%$ of TCNs were in employment, compared to the $78 \%$ employment rate of migrants from EU/EFTA countries. The majority of TCNs with intermediate and higher qualifications from third countries were employed as unskilled or semi-skilled workers. This trend was particularly evident among women (STADTWIEN 2017, p. 10). One of the interviewees, who states the following, confirms this:

"The unemployment level of migrants is higher compared to that of natives. The main reason behind this is firstly the discrimination on the labour market, and secondly the undeclared employment of women." (Interview no. 3, Vienna).

At the same time, foreign diplomas - especially those from third countries - seem to count less than those issued by Austrian educational institutions do. As one of interviewee put it:

"Despite my efforts to find work in my profession (architect), it has been proven an impossible mission so far. It happened only once that I received an interview invitation, and this was after a personal interaction with a person that I had met by chance." (Interview no. 12, Vienna).

Conversely, another interviewee supports a different view about the labour market integration of Albanian migrants in Austria:

"The majority of Albanians in Austria work in jobs and sectors that are according to their educational and qualification status. Thus, their professional capital is properly evaluated. In Austria, there is a scrupulous system of the professional identification of an individual. If you are diligent in your work, the doors are and remain open." (Interview no. 9, Vienna).

At the local level, the role of the City of Vienna has been considered successful in obtaining positive results by means of a pro-active employment policy involving the social partners.

"Since the 1990s, the integration fund of the Government of Vienna has contributed to networking and job placements in specific professions, such as electricians and plumbers." (Interview no. 3, Vienna). 
In the case of Greece, it has been observed that during the economic growth period of the 1990s, a number of factors played an important role in the attraction of migratory flows mainly from Albania. These include the improvement of living standards, the openness and seasonality of certain sectors of the Greek economy, and the relatively easy geographical access in conjunction with the so-called 'developed model' of informal economy. The dynamic of these developments consolidated a new type of labour division, where immigrants and native population were employed in 'parallel labour markets' in different sectors and professions. Immigrants mostly occupy unskilled (and seasonal) jobs, often below their educational qualifications in sectors characterized by the production of intensive labour, such as the construction sector and agriculture, and/ or by informal activities such as domestic services (IOSIFIDES et al. 2007). According to an interviewee:

"... a big issue of the Greek labour market is the complexity and opacity of the insurance system. It is so complicated, difficult and opaque, that the migrant was led to believe that (he) was to be directed towards uninsured work." (Interview no. 4 , Athens).

From a gender perspective, a large part of Albanian women in Greece provide undeclared care services and their status is regulated for family reunification purposes. It is not a coincidence that $63 \%$ of TCN holders of residence permits for 'family reunification' in 2018 were women $(129,206$ out of 204,841). An interviewee supports that:

"Concentration in the home and care sector prevents migrant women from accessing Greek language learning programmes as well as active employment policies (training, career guidance and labour market integration, unemployment benefits, and so on). Gender inequalities and discrimination in the labour market are even more acute for migrant women who are single or single mothers." (Interview no. 10, Athens).

The educational qualifications of immigrants are not recognized as equivalent to the corresponding degrees of native workers. During the past twenty-five years, both immigrants (first generation) and their children (second generation) have been excluded from access to several professions, despite the fact that they hold the necessary educational and professional qualifications (Interview no. 15, Athens). The onset of the economic crisis in Greece in 2010 deeply affected the economic and social conditions of Albanian migrants.

“...migrants still remain trapped in the vicious circle of ensuring the insurance stamps, unstable work and temporary residence permits. Some lost their residence permit, others found a half solution due to the introduction of the Code of Migration and Integration (in 2014), but in fact not all of the population was covered, and this relationship of dependency of legality from the economy and the labour market for migrants plays a huge role." (Interview no. 12, Athens). 
However, according to EL.STAT (2018), the share of foreign citizens in the national labour force was $69.5 \%$ in the $2^{\text {nd }}$ quarter of 2018 , showing a slight increase compared to 2017 (66.7\%). Migrants' participation in the labour market exceeds that of Greek citizens by more than $18.2 \%$. Yet, in 2017 , the unemployment rate of Greek citizens was $8 \%$ and $6 \%$ lower than that of foreigners, whose unemployment rates stood at $29 \%$ and $25 \%$ in 2017 and 2018, respectively. At the same time, the flow data on Albanian seasonal workers show an upward trend in 2018, compared to 2017.

Housing is considered an integral part of immigrants' integration in urban areas (Bosswick et al. 2007, p. 1). Indeed, a concrete spatial location is not just a geographical reference of individuals' everyday lives, but also a means of accessing different activities and life chances. Moreover, a particular location also reflects the type of housing and the special socio-economic status of the people who live there.

In Vienna, the housing patterns are shaped largely by the residential structure and opportunities available on the local housing market. On the residential social or class 'map' of the city it can be seen that people from traditional guest-worker states (Turkey and former Yugoslavia) are concentrated in residential areas located in the western working class districts, while other (elite) foreign citizens can be found in northwest Vienna (KOHLBACHER et al. 2012, p. 15). One interviewee maintains that that segregation is not a problem for Vienna:

"Today, migrants live everywhere in city centre. In Vienna segregation grows less and less important." (Interview no. 10, Vienna).

However, another interviewee expressed concerns about emerging ghettoization trends:

"The new far right government is planning to build houses for refugees in certain neighbourhoods located on the outskirts of the city. This could be very dangerous because of the potential of creating ghetto neighbourhoods." (Interview no. 2, Vienna).

The City of Vienna has become known for implementing specific policies focused on social housing. As two interviewees pointed out:

"About 1/3 of the population lives in social housing that is owned by the city of Vienna. Indeed, the City of Vienna is the biggest (property) owner among public institutions in the entire Europe." (Interviews no. 3 and 10, Vienna).

This has not always been the case. As the same interviewees support:

"Until 2004, migrants were not allowed to enter social housing programmes. Back then only Austrian citizens had the right to occupy public housing, while migrants were left in the hands of the private market." (Interview no. 3 and 10, Vienna).

Since then, access to subsidised housing for migrants has required the fulfilment of certain criteria, such as holding a long-term residence permit, and German language proficiency at level B1. 
In Athens, there is an observed pattern of migrant concentration in apartment blocks in the city's central districts. This is primarily due to the urban model of development that was marked by the access of migrants to a large, affordable housing stock. More specifically, Athens is a mosaic of contradictions regarding design practice, the form of the urban structure, and social stratification. The unique and particularly complex social geography of the city's urban space in combination with present-day economic circumstances is the context within which differentiations in the choice of housing for migrants must be sought. The following excerpt illustrates the situation:

"In Athens, there is no housing policy for migrants. Currently, the main problem with migrants and newly arrived refugees is housing. We have submitted project proposals to UNHCR to rent apartments that will accommodate them." (Interview no. 13, Athens).

At the same time, this heterogeneous population tends to settle in a disorderly fashion, with little planning, transforming Athens into a 'chaotic city'. All of these factors have led to particular and very differentiated spatial models of organization in the city. Spontaneous urbanism ${ }^{32}$ (LEONTIDOU 1990), as well as the structure of the process of production in combination with informal forms of employment, contributed to the creation of multi-functional but socially homogeneous areas and neighbourhoods in the city centre. Low prices, in combination with the central position of these areas, tend to attract migrants and members of low socio-economic strata in general, who either rent or seek to acquire their first home in these areas. In the wake of the refugee crisis, the Municipality of Athens has taken ad hoc initiatives in order to cope with accommodation (rather than housing) needs of newcomers:

"We try not to leave people sleeping in the squares of Athens. To cope with that, we constructed the refugee camp in Eleona. It would be good if those people, instead of staying in Viktoria Square, found suitable places at Eleona camp ... at least there the refugees' health issues have been covered by NGOs. The Municipality has neither the capacity nor the staff to cover their needs." (Interview no. 13, Athens).

\subsubsection{Cultural-Religious Dimension}

One of the crucial questions pertaining the cultural-religious dimension concerns the efficient management of increasing cultural and religious diversity in modern societies. From an individual perspective, culture and religion are perceived as a private matter, comprising a set of perceptions and practices of both migrants and the host society. The reciprocal perceptions of and reactions to difference and diversity seem to be more important, however (Garcés-Mascareñas and Penninx 2016, p. 115). Here

32 Spontaneous urbanism refers to the process of unplanned urbanization whereby informal housing became the rule, regardless of the available infrastructure in the greater area of Athens and Piraeus. 
again we would distinguish between two scenarios. In the first scenario, diversity must be ignored and migrants must be assimilated into the cultural and religious realm of the host society. The second scenario is based on the hypothesis that in a pluralistic social system, ethnic and cultural diversity is accepted and respected in public life. Certainly, there are various intermediate positions between the two scenarios. These could be intertwined with values and beliefs, with popular culture and everyday practices such as inter-ethnic social contacts, and with religious practices.

Social interaction: In the new social environment of the host country, immigrants usually develop new links and contacts that extend beyond the in-group and/or intergroup contacts, focusing mainly on interaction with members of local communities.

The City of Vienna has put forward initiatives to cater to specific ethnic groups, which - according to scholars - do not contribute to create a strong inter-ethnic mix. As emphasized by the study of DAHLVIK et al. (2017), 50\% of the initiatives in Viennese neighbourhoods result in partial interethnic encounters, while $50 \%$ do not result in interethnic encounters at all (p. 16). Albanians in Vienna appeared to maintain stronger social bonds with their community rather than to develop social bridges to locals:

"Albanians usually live in a virtual kinship community that meets once or twice a month.” (Interview no. 9, Vienna).

Students display a somewhat different picture concerning their social contacts, which depends on their social environment, but again the trend is slightly in favour of social bonds:

"Social contacts are more often with co-fellows from Albania with whom I have been to school in Shkodra. But I also keep contacts with Austrians and other students coming mostly from countries of former Yugoslavia." (Interview no. 13, Vienna).

On the other hand, the cultural differences seem to create a barrier in the way in which both Albanians and Austrians perceive social contacts:

"There are differences in social contacts with Austrians. For example, even if we worked together on the same projects, once we were out of the school environment, they left in different directions without talking to you anymore, as if we did not know each other." (Interview no. 13, Vienna).

In Athens, social relations with locals appear weak, whereas social capital (family/ relatives and ethnic networks) of Albanians seems to play an important role (IosIFIDES et al. 2007). This is mainly attributed to the dominant, negative public image of Albanians in Greek society.

"My parents took me to Athens when I was two years old. My experience there was marked by a racist flavour of natives. I recall specific moments during my elementary school where I tried to hide my Albanian origin and identity because of 
the public outcry against Albanians and Albanian children waving the Greek flag during national ceremonial events." (Interview no. 12, Vienna).

Religion: In stark contrast to Greece, Austria has adopted an Islam Law that came into effect in March 2015. The law, which was drafted in close cooperation with Muslim associations, ensures Muslims the right to practice their religion and specifies the rights and duties of the various Muslim denominations (BIfFL 2017, p. 166). With reference to Albanians, two interviewees gave the following picture:

"There is a religious tolerance in Austria. There are 30 mosques in the entire Austria, 8 of which are Albanians' and there is also an Albanian Catholic mission. " (Interview no. 1 and 3, Vienna).

As the fieldwork showed, the religious communities in Vienna are well organized. Furthermore, they are entitled to propose and approve the appointment of religious teachers in schools. Ultimately, the City/Province of Vienna is responsible for recruiting teachers and for ensuring the principle of secularism. An interviewee also highlights this:

"Two aspects are significant: the native language classes and religious education in schools. In the case of religious classes, the teachers are recruited after the approval of the religious community." (Interview no. 4, Vienna).

At an organizational level, the Muslim community in Vienna has a rotating presidency with the participation of all ethnicities, although Turks outnumber the other ethnic communities (Interview no. 4, Vienna). Given the specific religious beliefs of Albanians, it is no coincidence that they appear to be rather inactive, as is illustrated in the following excerpt:

"Albanians are not at all active in religious life in Vienna. Those who are active are the Albanians coming from Macedonia." (Interview no. 9, Vienna).

It becomes even more problematic when the Albanian state is equated with the Muslim religion, as has been pointed out by an interviewee:

"The fact that the majority of mosques bear the inscription 'Albanian Cultural Centre' is really worrisome. This identifies the Albanian state with a religion, which is not the case." (Interview no. 9, Vienna).

In Greece, on the other hand, the constitution recognizes Greek Orthodoxy as the 'prevailing religion'. Notwithstanding the fact that the Muslim religious communities (mostly identified with the minority of Thrace) has a long-held status as official religious legal entities, Athens remains the only European capital without an Islamic mosque.

Discrimination and xenophobia: discrimination is a result of the host society's negative attitude towards migrants. It can also be the result of institutional structures and processes, the practices of which systematically counter the interests of migrant groups. On the subject of institutional discrimination in the case of Vienna, an interviewee maintains that: 
"In Vienna there is no structural discrimination." (Interview no. 3, Vienna).

Another interviewee whose experience in dealing with the municipality of Vienna is rather gloomy, however, opposes the above opinion:

"The main problem is the documentation and the bureaucracy of the renewal of residence permits or visas. Perhaps for subjective reasons, my residence permit has been delayed. The reason was that, although the contract of the house is in my name and in that of my fellow student, they denied accepting it, because the previous resident had not declared (his) change of residence. The clarification of this caused a delay in the renewal of the visa and after the visa was finally issued, I was told that I have overstayed the 3 months of free stay in Austria and I had to go to Albania to get a visa and to go back again in order to claim the residence permit. When I went to Albania, I was fined 650 euro for violating the residence permit in the Schengen area." (Interview no. 13, Vienna).

Similarly, the following excerpts illustrate that the institutional discrimination is 'legalized' today because of a phobic attitude towards diversity, where diversity and the 'others' have been ideologically stigmatized:

"What happened in 2015 with the refugee crisis has adversely affected the situation. Now, the system in general has become very scrupulous. Some days ago, there was an Albanian student whose stay permit was rejected because he had $€$ 6,950 in his bank account instead of $€$ 7,000 (as it is required). On another occasion, while the father had deposited $€ 20,000$ in his son's account, the stay permit was again rejected based on the assumption that the amount and the source of the money in the student's account was large and unjustified." (Interview no. 9, Vienna).

Another interviewee approaches the subject from a different angle and brings his own version of the reality:

"The reason behind this behaviour is the rise to power of far-right forces and their policies towards migrants. The attitude of public officials concerned is not that of ordinary people, they have a different code of communication. They get very arrogant and rigorous when it comes to laws, but the obligation to keep them is placed on migrants. For example, when they make a mistake that consists in not providing you with a document, they blame you for not having asked for it." (Interview no. 13, Vienna).

An interviewee in Athens articulates the same concerns:

"Obviously the other big problem is that, in recent years, we have unfortunately seen an increase in the phenomenon of racist violence, especially in Athens. This was expressed both at the central political level and in the Municipality, with the dramatic rise of far-right forces on the political stage." (Interview no. 12, Athens). 
In Athens, Albanian migrants face a number of obstacles in the process of integration, which are mainly due to the institutional constraints that feed discriminatory practices:

"...there is an institutional discrimination which comes as result of the refusal of access to Greek citizenship and to the exercise of political participation rights." (Interview no. 5, Athens).

Contrary to the above opinion, what seems to prevail at municipality level is the principle of equal access and rights for all people regardless of ethnic origin:

"As far as the Municipality's philosophy is concerned, it has been explicitly stated that all those living in Athens have equal rights and opportunities and there is no discrimination in terms of benefits...there is no discrimination. The general perception actually prevailing is that the Municipality has to provide for residents and citizens accordingly to their needs." (Interview no. 8, Athens).

Another interviewee, meanwhile, accepts that racist incidents have been recorded, involving municipal police:

"There have been, however, various racist incidents in the Municipal Police, who are responsible for the licensing of stores in the health branch. They did not give permission to migrant businesses, even though they forced them to make large investments." (Interview no. 3, Athens).

In Austria, in daily life, discrimination and racism pose serious obstacles to immigrants' access to important resources of survival such as in the area of employment.

"There is a hidden discrimination mainly in certain sectors of employment. For example, from 7,000 police, only 300-400 are of migrant background. Even though they formally fulfil the conditions, they usually 'fail' in psychological tests that are subjective." (Interview no. 3, Vienna).

Thus, for example, institutional discrimination can occur when the right to employment in the public sector only applies to the native population:

"No migrant is employed in the municipal or social services of the municipality of Athens. I think it would be very important to give the proper message to the citizens. It is a way of accepting those people being an equal part of the city life." (Interview no. 4, Athens).

The dimension of social interaction in relation to discrimination and racism is determined by the duration of contact between immigrants and the native population. Some arguments underline that the prolonged time span of the inter-group contacts reduces prejudice, while others, on the contrary, argue that biases may increase with time. The following interviewee confirms the former opinion: 
"Interestingly, in places where there are no migrants and as such their presence is not visible to locals, the latter are far more conservative than those who have come into contact with migrants." (Interview no. 9, Vienna).

However, the possibility does exist that discrimination and racism may increase (rather than decrease) when the number of migrants increases and their presence becomes more visible (in public places in particular), while their presence is seen as a threat to ethnic homogeneity:

"Because Austria is a small state, there is an increasing phobia towards immigrants or other ethnicities coming from large states. In a way Austrians see their homogeneity in peril - they are very sensitive to religious affiliation." (Interview no. 9, Vienna).

Comparing Austria and Greece, an interviewee makes the following distinction:

"In Vienna, the people are formally polite but in my daily experience their attitude is discriminatory and exclusionary, something that doesn't happen in Greece. There, the ordinary people are not very polite. They would openly express any feeling and stereotype about foreigners without following any code of conduct. But when it comes to daily life, they support you and provide help without hesitance." (Interview no. 12, Vienna).

It thus becomes clear that both Austria and Greece are multicultural societies and that the imaginary homogeneity remains a myth. Officially, both Austria and Greece refer to pluralism and the positive integration of migrants, although the country's lawmakers represent the Austrian and the Greek cultural and identity as homogeneous. Austrian and Greek citizenship remains based on ius sanguinis. In contrast to Greece, where dual citizenship is accepted, migrants in Austria have to renounce their previous nationality, although certain exceptions to this rule are often made. In fact, in both countries, naturalization is considered a 'reward' (JURADO 2008, p. 5) for a migrant's assimilation, rather than as an institutional tool for enhancing integration (BAUBÖCK 2006; KYMLICKA 2003). To this end, both states subscribe to the above view and demand that migrants pass naturalisation tests that include high levels of proficiency in the host country language as well as knowledge of the history and culture of the state. Applicants for citizenship should furthermore subscribe to the public values in the case of both states.

With regard to Albanian migrants in Vienna, it was observed that they are hardly organized around the community. They are assimilated, which is also reflected by the fact that the second generation does not speak the Albanian language. This can also be justified by the fact that most of them have obtained Austrian citizenship, which means that they automatically have lost Albanian citizenship. Another element that confirms the assimilation pattern of Albanians is the fact that, despite the opportunity provided to attend Albanian language courses at school, Albanians are generally not willing to participate. As attested by interviewees, the aim much rather is to come as close as possible to the Austrian model of living, which means to avoid any customs or actions 
that might make Albanians look different from Austrians. Again, it is maintained that Albanians tend to self-assimilate, which in turn is viewed as an approach of conformity with the existing system of the country of destination, which shows a trend of "positive integration'. The same pattern emerges when talking about the second generation in Greece. They rarely speak any Albanian and even in a situation of crisis, instead of going back to Albania or staying in Greece, they opt for moving to other Western countries.

At the local level, integration policies mainly focus on two realms: German language courses and public housing for all. However, the first and ultimate requirement is learning the German language. Although the Municipality of Vienna's room for manoeuvre is very limited, there is a broad agreement between municipal authorities and national policies that labour market integration and professional training are important goals. In Athens, on the other hand, there is no clear plan or tailor-made local policy for integrating migrants and there are no mechanisms towards reaching this goal. Migrants have achieved a certain degree of integration on own initiative, without any contribution by local government. This could be called one-way rather than two-way integration.

\subsection{Transnationalism}

For migrants, being transnational means embarking on multiple relationships and establishing 'double engagement' in more than one place, while being simultaneously 'here' and 'there' (Grillo and Mazzucato 2008). To study transnationalism, scholars have attempted to classify transnational activities by distinguishing between economic, political, and socio-cultural dimensions (PORTES 2001, p. 187). Economic activities include remittances and investments in the home country, which, in turn, could pave the way for an emerging new component, namely the return to the country of origin (KING and Collyer 2016, p. 179). Political activities encompass, among other things, ideas about democracy, transparency and participation in home countries' national elections in a form of transnational political capital (MüGGE 2016, p. 111). On the other hand, transnational socio-cultural activities could be interpreted in the light of socio-cultural capital that entails ideas, behaviours, identities, morality, and cultural codes that are eventually dependent on the level of migrant integration in countries of settlement (LEvitT 1998, p. 926). Not all migrants are however necessarily involved in transnational activities. Some eventually become more deeply integrated or assimilated and therefore alienated from their countries of origin, while others may not be able to or do not prefer to engage with their homeland (Grillo and Mazzucato 2008, p. 185). An interviewee corroborates this:

"The more integrated in Austria, the less transnational they are, since their daily lives and direct interests in raising and educating children and buying a home are already in Vienna." (Interview no. 3, Vienna). 
In the case of Albanian migrants in Greece, several forms of transnational activities have been observed. A study of KING and VulLnetari (2009) indicated that the transnational practices of Albanian households in Greece are increasing and there is an emergent transnational social space. At the same time, research by MichaIL (2009) had shown that proximity with Albania facilitated migrants' transnational investment practices while keeping their connections with family members and places of origin quite strong. It has further been argued that transnational activities of Albanians increasingly denote a strategy of integration as an alternative answer both to the economic and political instability in Albania and to the problematic migration environment in Greece (Michail 2013, p. 266). Recently, however, Albanian migrants in Greece have been going through a new transnational rupture due to repercussions of the economic crisis in relation to their legal and socio-economic status. They are, therefore, neither able to sustain a decent standard of living in Greece nor to create a new and viable livelihood back in Albania, which remains poor and disorganized (KING et al. 2013, p. 137). Therefore, transnational patterns and activities are changing and transnational practices are being modified. Some practices cannot be performed to the extent to which they once were, while others cannot be performed at all (e.g. remittances and investments) (GEMI 2014). In addition, given the liberalisation of visas (introduced in 2010) and the consolidation of long-term resident status along with the increasing access to citizenship, both in Austria and Greece, a new dynamic of transnational space has emerged with transnational movements becoming easier and more fluid.

"Everybody is expecting to take Greek citizenship and immediately leave the country to find better life opportunities abroad. The number of Albanians who were born in Greece or those who came here at a very young age is estimated at 120,000." (Interview no. 7, Athens).

In this sense, transnational practices and activities followed by Albanian migrants situate them within the realm of transnationalism. Transnational transfers however are connected explicitly with patterns of deeper integration/assimilation in Austria vis-à-vis social exclusion $^{33}$ in Greece. The questions raised here are, first, in what ways do Albanian migrants resume transnational activities and how do they construct new transnational bridges between countries, since the crisis in Greece (that has caused social exclusion rather than deepening integration) has created a new and different set of transnational engagements? Secondly, does migrants' integration/assimilation in Austria reinforce or deter transnational activities? Is there any trade-off between transnational activities and integration/assimilation? In other words, the more integrated migrants are in their country of settlement, the less transnational they might be and vice versa.

33 Which, before the economic crisis, was characterized as one-way assimilation. 


\subsubsection{Economic transnational transfers}

To a great degree, Albania relies economically on remittances from migrants. Remittances are seen as the most important financial contribution of migrants to the development of the Albanian economy. This is applied even in Austria, albeit on a much smaller scale than in Greece.

"There is a limited economic transnationalism, it relates only to remittances and small economic aid for the reconstruction of houses." (Interview no. 3, Vienna).

Remittances have long helped to overcome poverty and for many years continued to make an important contribution to the Albanian economy. Although Albania continues to be heavily dependent on remittances, the inflows gradually declined during the economic crisis in Greece. An interviewee recounts how the lack of remittances has had an impact on the living conditions of families back in Albania:

"Most of the Albanians in Greece used to send money on a monthly basis. With that money, their relatives there built houses and supported the domestic economy [...]. Now, since many Albanian workers can wait for months to get paid for their jobs, if not unemployed, they are not able to remit as they used to." (Interview no. 15, Athens).

Strengthening contact with family networks in Albania initiates a new and unfamiliar dependency for Albanian migrants particularly in Greece. In some cases, they appear dependent upon family members in Albania to send remittances to them in Greece - the so-called 'reversed remittances'. In addition, many feel the need to overcome a marginalized socio-economic status caused by the crisis and therefore encounter greater difficulty trying to fulfil goals, such as maintaining affordable and quality education for their children. Attempts to do so have led Albanian families to send a part of their family to Albania.

"There are Albanian families split up in two between Greece and Albania. As the husband was left without any money and job, he decided to return to the family apartment in Tirana with the older son, while the wife continues to work as a house cleaner in Athens, putting in efforts to help her children to move forward with their studies." (Interview no. 7, Athens).

As the stability of remittance flows is dependent on the migrants' legal status and position on the labour market, the impact of the financial crisis in Greece along with the decrease in remittance flows qualifies as the main transmission channel of a domino effect within the economy of Albania. In fact, apart from Greece, Albania is the country most affected by the spillovers of the Greek crisis for two reasons. First, as already mentioned, Greece is the most important country for Albanian remittances. Secondly, for Albania, Greece has been and still is the main trade partner and the main country for foreign investments (SADIKU and BERISHA 2014). Conversely, the economic presence and investments of Austrian companies in Albania, especially in banking and in the financial 
sector, have increased the transnational mobility of financial capital and human capital (staff), with the latter benefitting from further qualification and employment in both countries:

"The Austrian economic presence in Albania is quite evident and this creates transnational space, as staff can be mobile from one country to another." (Interview no. 9, Vienna).

However, when it comes to Albanian economic transnational activities in Vienna and vice versa, it is found to involve a small, restricted group of persons with specific socio-economic features:

"There are cases of some Albanian businessmen who have brought children and family to Austria to study and in this context have done some business." (Interview no. 9, Vienna).

\subsubsection{Return}

When examining the interconnectedness between integration and transnationalism, it is assumed that return does not constitute the end of a migration cycle, but that it rather is part of a transnational system, which is based on the interconnection of social, cultural and economic relationships cutting across traditional (national) borders. In the recent past, returning to Albania had been considered as an indication of failed integration. During the crisis in Greece, however, return was seen as a strategy for coping with the detrimental impact of the economic crisis on Albanian households (GEDESHI and DE ZwAGER 2012, p. 250). As an interviewee put it:

"From 2008 onwards, with the beginning of the crisis, there was a considerable degree of return. We are talking about a total of 220,000 people returning to Albania since then." (Interview, no. 7, Athens).

Interestingly, the Austrian case represents precisely the opposite scenario. Return is not seen as an option, due to the advantages offered by the Austrian integration system and through economic stability:

"Return, no way [...] Maybe only retirees on a seasonal basis. Here in Austria, the benefits for old age are fantastic. There is a perfect infrastructure for the elderly." (Interview no. 3, Vienna).

Even in cases of a temporary legal status, return is not considered an option. An interviewee explains his approach as follows:

"I don't want to return to Albania. I want to stay in Austria. Here I feel at home and secure, regardless of offensive behaviour [...]. In Albania there is no room for any kind of business development, because if you have an idea and make it reality, a politician would come and take it from you with (a mere) 'because I say so', and then tell you to 'go now', because he/she controlled the market. I would go to work in Albania only if an Austrian company sent me there. If I don't find work in Austria, I will go to Germany." (Interview no. 13, Vienna). 
Back in Greece, several interviewees followed multiple geographical paths, and pursued many ventures before taking the decision to return to Albania or to Greece (Interview no. 7, 14, 15, Athens). In some cases, the return decision might reflect weak integration in Greece, or it would be an indication of preparedness for the return scenario. In other cases, the economic crisis might have precipitated the return of those who have completed their project of transferring capital and thus to some extent have satisfied the dream of developing their own venture in Albania.

"Before returning to Albania, some migrants took all their savings from Greece and transferred them to Albania. They had realized that the crisis was approaching and, being afraid of losing them, they transferred their savings in Albania through informal channels. Later on, some of them returned (in 2013 or 2014) and used the money to run their own business or to buy apartments." (Interview no. 14, Athens).

However, our empirical findings revealed a rupture compromising the capacity for development and business activity, and therefore for furthering goals of upward socioeconomic mobility. As an interviewee puts it:

"Returnees are left without visible or viable options. Entrepreneurship initiatives, for instance, are often obstructed by instability and lack of infrastructure, and of re-integration policies for returnees in Albania." (Interview no. 14, Athens).

For obvious reasons, this is not the case for Albanian migrants in Vienna, even when they have made professional and economic investments:

"I have never thought about return. I go to Albania simply to develop 1-2 professional projects a year as it was with the dance project 'Exile-Déjà vu'. Austria is my home. The only investment I have made in Albania is buying a summer house by the sea." (Interview no. 5, Vienna).

Clearly, this study shows that the attitude towards return has primarily been developed through a transnational understanding and evaluation of opportunities in both the home and the host country. As such, the findings offer significant evidence on how return does not constitute the end of a migration cycle, but instead is part of a transnational system, an episode in the process of transnational transfers. The intentions of these transfers are shaped by changing circumstances (e.g., personal experiences or contextual factors in the sending country), and strongly influenced by transnational life opportunities (NADLER et al. 2016, p. 361).

\subsubsection{Political transnational activities}

One of the key parameters of political transnational activity is that migrants' political integration in countries of settlement can occur simultaneously with transnational political practices (MARTINIELLO 2005). This happens because opportunity structures that allow certain degrees of participation are shaped by both the receiving country 
and the sending country (MüGGE 2016, p. 116). It is assumed that active transnational political engagement can contribute both to the democratization of the country of origin and to the evolvement of a multi-cultural democracy in the receiving countries (FAIST 2000). In this context, the political opportunity structure (in countries of origin and settlement) as embedded in national integration policies, as well as the citizenship regimes are considered to be the feedback mechanisms through which migrants' political transnational mobility is being shaped (LEVITT et al. 2003, p. 654; BAUBÖCK 2003).

In Greece, migration policies have perpetuated a model of managing migration that has stressed security issues, stricter border controls, and legalization procedures, and had not promoted the real issues related to full integration, access to citizenship and political participation. However, contrary to the citizenship regime in Austria, dual citizenship is recognized in Greece. Following the same line of reasoning, it is assumed that a strong transnational political orientation is a response to exclusionary citizenship regimes (e.g., recognizing or not recognizing dual citizenship) limiting migrants' access to the political community in the host country (Koopmans et al. 2005, p. 143). In contrast to this approach, the level of political participation of Albanian migrants both in Albania and in Austria and Greece has been historically very low in reality.

"Albanians have no connection with the political scene in Albania." (Interview no. 9, Vienna).

Meanwhile, as supported by MorawsKa (2003, p. 161), active political participation in the host society and political engagement in the country of origin are often successfully combined. Again, this approach is applicable neither in Greece, nor in Austria. An interviewee explains that this is due to the homeland's manipulative stance toward political participation in the host country:

"Albanians are out of political developments in Austria. They are greatly indoctrinated by the countries of origin, Albania and Kosovo, and they show no interest for Austrian political life. Homeland political parties play a negative role because they want to control them and thus do not motivate them to participate in Austria." (Interview no. 3, Vienna).

In Greece, on the other hand, the perceived temporary character of migration is restricted to presence rather than participation. In this context, active civic and political participation as well as the representation of immigrants in mainstream associations like trade unions or political parties has not been facilitated at all (GROPAS and TRIANDAFYLLIDOU 2005, p. 4). The main reasons include the insecure legal status, the prolonged immigration policy vacuum, which has reinforced the feeling of mistrust towards the Greek state, and the exclusion, until recently, from access to political rights and citizenship status. Unlike in Austria, where the electoral interest is insignificant, in Greece, the three major Albanian political parties (PS, PD and $\mathrm{LSI}^{34}$ ) have recently put in significant efforts to engage Albanian migrants in political developments in Albania. It has been estimated that a large number of Albanian migrants living in Greece have

34 Socialist Party, Democratic Party and Socialist Movement for Integration. 
travelled to Albania in order to cast their vote in the national election that took place in June 2017. The question raised here is whether this development is perceived as a form of 'negotiating' the option of return as a result of the ongoing crisis in Greece, or whether it marked a new historical phase in transnational political participation of Albanian migrants. One of the interviewees supports both notions:

"Albanians went to vote because they believe it could help them to establish social and political ties with the (corrupt) system there. It is seen as a strategy to network and find a work for themselves and their children in Albania, given the precarious situation in Greece." (Interview no. 15, Athens).

\subsubsection{Socio-cultural Transnational Activities}

Transnational socio-cultural activities could be viewed in the light of socio-cultural capital that entail ideas, behaviour and identities, feelings of belonging, morality, and cultural codes. It could also be seen as a form of attachment to the country of origin and attachment to, or integration/assimilation in the host country (ENGBERSEN et al. 2013). As our case study demonstrates, the connection between homeland attachment and integration is not mutually exclusive:

"I began establishing professional contacts with Albania in 2013 when my former teacher was appointed director of the Albanian Opera and Ballet Theatre. Then I became a member of the opera board and started performing on the Albanian stage. Albania connects me with my childhood. I am Albanian. I feel Albanian. I miss Albania. The motive behind my activities in Albania is the desire and the need that I feel to offer my contribution to the development of ballet and cultural life in my country. Thus, I aspire that Albania shall not be considered a backward or primitive country. My goal is to transfer the knowledge, experience and technique that I have learned in the West. I usually go to Albania once a year for work reasons and every summer for 5-6 weeks for vacation with my family at a summer house that I have bought years ago." (Interview no. 5, Vienna).

As illustrated above, integration can go hand in hand with either strong or weak forms of transnationalism, but this category consists mainly of highly educated migrants who work in skilled professions. This approach could also be promoted by pro-active policies in the fields of cultural and educational cooperation between the country of origin and the host country.

"Austria attaches a lot of significance to cultural aspects, for example, they have put forward projects to promote the German language in Albania and to increase the number of German-speaking people." (Interview no. 9, Vienna).

Conversely, in Greece, de-legalization and exclusion are pondered as an emerging phenomenon in transnationalism. In this sense, transnationalism serves more than just an integrative and reproductive purpose, because exclusion adds a new dimension to the 
transnational narrative in which ties are severed and belonging is negotiated. While the first generation attempts to reconcile the rupture caused by having to choose between places - returning to their country of origin, or migrating to a new country - the second generation is struggling with identity. Many of the latter are technically Albanian because it is the origin of their parents, but they were born, raised and socialized according to Greek cultural norms and values. To them Albania means belonging to their parents' homeland while returning to their families' roots (WESSENDORF 2007, p. 1097). However, once in Albania, they feel trapped in a place which they once hoped would be their home, but in which they feel like strangers. Interestingly, as a recent study (GEMI 2015) has shown, a significant number of second-generation migrants of Albanian origin put into question their ethnic attachment to both Greece and Albania. Instead, a cosmopolitan identity seems to prevail.

In conclusion: it has become clear that economic transnationalism requires financial capital, e.g. for remittances or/and investments. Political transnationalism requires political capital in the form of skills, knowledge and contacts in the homeland, while socio-cultural transnationalism requires social capital in the form of social networks (MüGGE 2016, p. 120). The rationale behind this approach is that migrants who are low on the economic, socio-cultural, or political ladder are supposed to be less likely to engage in transnationalism. As this study shows, the types and forms of transnational activities depend primarily on the level of integration or exclusion in the host country. It also depends on the openness of opportunity structures in the homeland, which is materialized through pro-active diaspora policies. In the case of Albanian migrants in Vienna, it becomes clear that deeper integration/assimilation has led to more limited transnational activities, both in their form and their intensity.

"Not too much transnational mobility. It is limited to occasional or professional interpersonal relationships." (Interview no. 9, Vienna).

At a national level, transnationalism seems to be significantly related to the inter-EU mobility of migrants, who are used to frequently go back and forth between locations. An interviewee addresses the matter as follows:

"For EU citizens, transnational mobility takes place because of legal facilities, elimination of physical barriers, and geographical proximity. When it comes to third-country nationals being transnational, it becomes more complicated because of legal status, longer distances to countries of origin, and the nature of bilateral relations with the country of origin." (Interview no. 10, Vienna).

By supporting the idea of assimilation, an interviewee goes a step further and delves into the ideological and political complexities of the 'Austrian version' of transnationalism:

"In Austria, transnationalism is seen as a threat. Sebastian Kurz, on a visit to Bosnia, declared that 'Bosnians should invest in Austria and not in Bosnia'. This is a kind of 'Austria first', nationalistic approach." (Interview no. 11, Vienna). 
Despite their commonalities in terms of restrictive citizenship, there are significant differences between the Albanian migration patterns in Austria and Greece. While migration to Greece has been mostly irregular, this is not the case for Austria. The different legislative and policy frameworks have affected migrants' regularization and, subsequently, their level of integration as well as the development of transnational patterns. At the same time, integration of Albanians in the labour market differs significantly between the two countries. Variations are mainly related to differences in access to the educational system, the characteristics of the labour market, and the nature of the opportunity structure. In Greece, some migrants experienced de-skilling and expressed frustration at not being able to enter the education system and enhance their professional qualifications in order to improve their position on the labour market. Likewise, transnational mobility patterns differ across the two countries. One factor that contributes to differences between locations is the matter of regularization and residence permits. In Greece, difficulties with papers have obstructed transnational movements to Albania and other countries. Before the liberalisation of the visa regime in 2010, the Greek authorities had from time to time allowed Albanians to travel home only during holidays. Undoubtedly, such restrictions influenced transnational transfers and transnational family ties of Albanians in Greece (VATHI 2015, p. 127). In fact, the incomplete legislative framework and the persistent refusal to accept the transformation of the country into a pole of attraction for migrants that characterize the first phase of Albanian migration (1991-1998), led to the long-term irregular stay and employment of Albanians, whereby transnational and circular (irregular) movements became the norm. However, certain political developments caused a cascade of events that are related to return, to the increase of transnational/circular mobility, and to the search for other migratory destinations. These developments include the liberalisation of entry visas for Albanian citizens entering the EU, the economic crisis, and the strong tendency of de-regularisation that followed, as well as the uncertain status of the second generation. The result of these developments is the creation of a particular category of migrants that constantly move between two countries. As shown by a recent study (GEMI 2015), the expanding possibility of legal entry into Greece has had the immediate consequence of enhancing the (irregular) transnational /circular mobility patterns for seasonal work. Increased transnational cross-border movements facilitate the mobility of the (by and large unskilled) Albanian labour force between the two countries, and its adaptation to new, even more flexible forms of labour relations because of the pressure exercised by the economic crisis in the labour market, both in Greece and in Albania.

As many studies have revealed, there is a dynamic transnational social space between Albania and Greece (King and Vullnetari 2010, p. 26; Maroukis 2010), whereas this is not the case for Austria. In this context, the immigrants' legal and socioeconomic status has played a crucial role in determining transnational mobility in both countries, as it allows (or does not allow) them to be highly mobile not only geographically, but also occupationally and socially. Now, it is a feature relevant for migrants still living in Greece, a trend going hand in hand with reactive transnationalism. To 
counter the risk of downward mobility, Albanian migrants respond to their obstacles by engaging less in immediate socio-economic spheres in Greece and participating more in transnational activities that transcend Greek 'porous borders'. The crisis has thus to a degree encouraged transnational mobility and return migration and has given migrants a renewed dynamism because of decreasing opportunities at their original destination, which therefore made conditions at their point of origin also seem more attractive. 